\title{
: \\ HOW CAN URBAN PLANNERS AND ARCHITECTS REDUCE INEQUALITY IN CITIES?
}

AS CITIES GROW, WHAT HAPPENS TO INDIVIDUAL NEIGHBOURHOODS WITHIN

THEM? THIS IS WHAT THE CENTRE FOR SUSTAINABLE, HEALTHY AND LEARNING CITIES AND NEIGHBOURHOODS HOPES TO FIND OUT. LED BY PROFESSOR YA PING WANG AT THE UNIVERSITY OF GLASGOW, UK, THIS COLLABORATION BRINGS TOGETHER ARCHITECTS SUCH AS DR JOSEPHINE MALONZA AT THE UNIVERSITY OF RWANDA AND URBAN PLANNERS SUCH AS DR SHILPI ROY AT KHULNA UNIVERSITY, BANGLADESH, TO EXPLORE HOW TO IMPROVE URBAN ENVIRONMENTS

TALK LIKE AN URBAN

STUDIES RESEARCHER

AKARUBANDA - the traditional

Rwandan concept of public open space

PULL FACTOR - something that encourages someone to move towards an area

PUSH FACTOR - something that encourages someone to move away from an area

URBAN SPRAWL - the rapid spatial expansion of a city due to unplanned, uncontrolled and scattered growth

URBANISATION - the proportional increase of population living in urban areas compared to rural areas

By 2030 , the United Nations predicts that $60 \%$ of the world's population will live in cities. While cities can provide residents with services and employment opportunities, rapid unplanned urban growth means these advantages are not available to everyone.

"Cities are very complex," explains Professor Ya Ping Wang of the University of Glasgow. He is the director of the Centre for Sustainable, Healthy and Learning Cities and Neighbourhoods (SHLC), an international research collaboration that hopes to better understand this complexity. The SHLC team is studying urban neighbourhoods in 14 cities in Africa and Asia, including Kigali and Huye in Rwanda, and Dhaka and Khulna in Bangladesh. Team members have a wide range of urban studies-related backgrounds, from urban planning, such as Dr Shilpi Roy at Khulna University, to architecture, such as Dr Josephine Malonza at the University of Rwanda, and from health to education. Their research will unpack the challenges of urbanisation and support the United Nations' Sustainable Development Goals, not only to ensure cities and communities are sustainable, but also to ensure those living in urban environments have good health and well-being, and access to quality education.

\section{WHY ARE CITIES GROWING?}

Cities offer opportunities for employment and social interaction, enticing migrants to urban centres, while poverty commonly drives migrants from rural regions. "In Bangladesh, unequal land distribution, inadequate education and healthcare, unemployment and displacement by natural disasters all act as push factors, forcing rural residents to leave," explains Shilpi. "Urban industries, income opportunities, better social amenities and improved livelihoods in cities all act as pull factors to draw rural people to urban areas."

Cities also expand in response to growing national populations. "The rapid urbanisation we are currently seeing in Rwanda is primarily fuelled by the high birth rate and resulting phenomenal increase of the country's population," says Josephine.

WHAT PROBLEMS ARE CAUSED BY URBANISATION?

Overcrowding, pollution, congestion, urban sprawl, overuse of resources and lack of access to amenities are just some of the problems caused by urbanisation. In Bangladesh, the number of slums has increased almost five-fold since 1997 as more people move to the cities, and over one in five urban residents live in poverty, highlighting how rapid urbanisation commonly leads to increased social inequality.

At the same time, cities generate large amounts of waste, which can end up in waterways or in the air that people breathe. Over half of all solid waste produced in Khulna is dumped on the roadside. "Unplanned urbanisation in the cities of Bangladesh has led to crowded and polluted living conditions, with urban services insufficient to serve the communities that live there," says Shilpi. Air pollution can have serious consequences not just for human health but for education. In 2021, schools were closed in the Indian capital of Delhi due to record levels of air pollution.

WHAT METHODS ARE THE SHLC TEAM USING?

Although urban sustainability is often discussed at city-level, the diversity within a single city means broad generalisations 


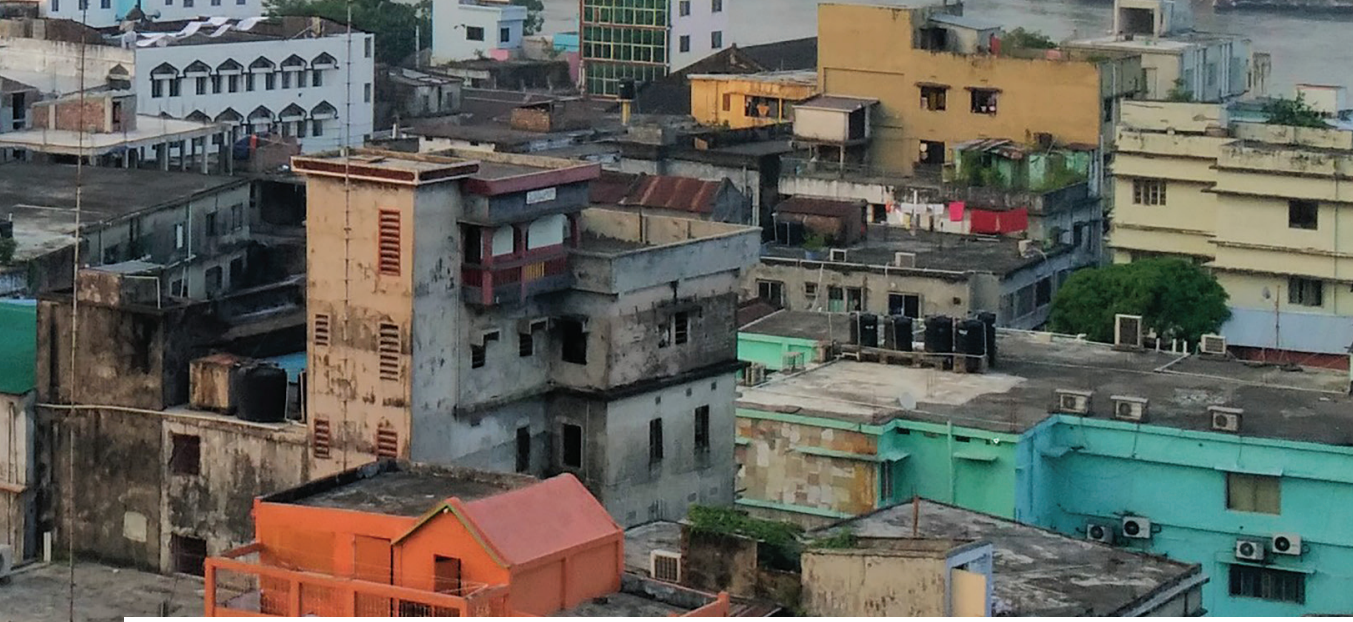

lose the intricacies of city life. The SHLC is investigating cities at a neighbourhoodscale to address this issue. "We carry out large-scale household surveys and focus group interviews in different types of neighbourhoods," says Professor Michele Schweisfurth, from the University of Glasgow. She is a professor of comparative and international education and a coinvestigator in the SHLC team. "This helps us to understand neighbourhood characteristics, including the demographic, social and economic composition of different districts within a single city."

Team members also statistically analyse official datasets to quantify urban growth and urban inequality. They use satellite imagery and visual observations to map out urban expansion and land-use change. And they review urban policy documents to explore how development is viewed and managed in the case-study cities.

\section{WHAT DO}

\section{NEIGHBOURHOODS NEED?}

For a neighbourhood to be considered a 'sustainable, healthy and learning environment', all residents within it should have access to educational, employment and healthcare opportunities. "The presence of affordable, quality and adequate facilities for all increases the living conditions of a neighbourhood's residents," explains Shilpi.

"If development opportunities are integrated in a neighbourhood, people commute lesser distances to access work, healthcare and education," says Josephine. "If a neighbourhood is vibrant, this will encourage healthy lifestyles, employment opportunities and economic growth."

Sustainable neighbourhoods should also reduce their impact on the natural environment. This requires efficient public transport services to reduce dependence on private cars and waste management services to prevent rubbish being dumped on streets and in waterways.

It is also incredibly important for urban neighbourhoods to contain open, unbuilt areas, such as parks. "Public open spaces are lifelines for communities," explains Josephine. "They help to improve our social, physical and mental health - all of the things which give life meaning." In Rwanda, there is a traditional concept of public space known as akarubanda. Shared social spaces in rural settlements provide opportunities for community members to gather and socialise, dance, share food and exchange words of wisdom. Through her research and engagement with policy makers, Josephine hopes to bring akarubanda back into contemporary Rwandan cities.

\section{HOW COULD URBAN}

\section{DEVELOPMENT POLICIES}

\section{IMPROVE CITIES?}

"More attention needs to be paid to improving city planning and regulation, especially prioritising neighbourhood-based development," Shilpi says. "This is necessary to deal with inequalities and the lack of services in growing urban areas." She and Josephine both advocate for improved urban development policies in their countries. These policies need a bottom-up approach, driven by community members and the needs of individual neighbourhoods, to ensure new urban development serves the people of the city.

Urban sprawl is a significant challenge in Rwanda and Bangladesh as informal settlements grow around cities. Josephine suggests a solution could be to create urban qualities (such as services and employment opportunities) in rural settlements, thereby minimising rural to urban migration and so reducing the pressure on cities. Shilpi hopes to see unified urban governance in Bangladesh, in which all the different agencies involved in city management work together to regulate development. She also highlights that all development policies should consider the environmental impact of urbanisation and industrialisation.

The research findings from the SHLC are already being communicated with stakeholders. Shilpi and the Bangladesh

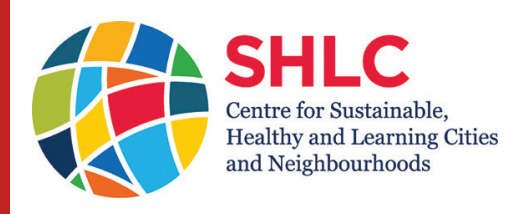

THE CENTRE FOR SUSTAINABLE, HEALTHY AND LEARNING CITIES AND NEIGHBOURHOODS (SHLC)

www.centreforsustainablecities.ac.uk

\section{PARTNER INSTITUTIONS}

University of Glasgow, UK; Khulna

University, Bangladesh; University of

Rwanda, Rwanda; Human Sciences

Research Council, South Africa;

University of the Witwatersrand, South Africa; Ifakara Health Institute, Tanzania; National Institute of Urban Affairs, India; University of the Philippines, Philippines; Nankai University, China

\section{FIELD OF RESEARCH}

Urban Studies

\section{RESEARCH PROJECT}

Investigating the sustainability of cities and urban neighbourhoods by assessing residents' access to healthcare, education and opportunities

$$
\text { ........... }
$$

\section{FUNDERS}

UK Research and Innovation (UKRI), Global Challenges Research Fund (GCRF)

team have shared their results with the mayors of Dhaka and Khulna and are now preparing policy briefs based on SHLC findings to ensure national urban policies promote sustainable, healthy and learning neighbourhoods. Josephine and the Rwandan team have met with stakeholders to plan how new policies can be implemented, and Josephine has been appointed to a joint sector review board at the Ministry of Infrastructure and a technical advisory group for the city of Kigali, where she can apply her research findings at government level.

The members of the SHLC are not only helping us understand cities in greater detail but are using their expertise to improve our urban environments. As Shilpi comments, "With a career in urban studies, you can really make a difference in the world!"

\section{ta}




\section{ABOUT URBAN STUDIES}

The world is rapidly urbanising. As people flock to cities in search of employment opportunities, urban populations are increasing faster than ever. As cities expand to accommodate this influx of migrants, urban planning has never been more important.

WHY DO CITIES NEED TO

BE PLANNED?

Cities cannot be left to grow spontaneously as they expand, as this results in neighbourhoods that do not have access to adequate infrastructure and services. In many cities around the world, unplanned, uncontrolled and scattered growth has resulted in informal settlements, or 'slums'. "In Bangladesh, wealthy neighbourhoods are almost all planned and offer quality services and facilities," says Shilpi. "In contrast, most poorer neighbourhoods are unplanned, with deficient urban amenities as a result." This unplanned development therefore deepens social inequalities.

"Planning is important as it helps cities to develop strategically, based on existing resources and a well envisioned future," Josephine explains. "Without this balance, cities would outrun their resources and end up in a complete mess."

WHAT ARE THE HIGHLIGHTS OF WORKING IN URBAN STUDIES?

"I am passionate about the quality of life in urban areas, and hence unpacking the multifaceted layers that urban societies have to navigate to enjoy life in cities," says Josephine. Working in urban design as well as architecture provides her with a wider perspective, giving her a deeper understanding of social life in the unbuilt parts of cities that architects do not necessarily engage with.

Shilpi is motivated by knowing her expertise in urban planning can promote equality in urban areas. "Rapid urbanisation leads to pollution, environmental degradation and inequality," she says. "Urban planning has immense scope for tackling these urban challenges and securing a sustainable future for urban residents."

\section{EXPLORE A CAREER IN URBAN STUDIES}

- Visit the Centre for Sustainable, Healthy and Learning Cities and Neighbourhoods to learn how experts in urban studies and related fields are applying their skills to improve urban environments around the world: www.centreforsustainablecities.ac.uk

- Josephine says that urban studies will enable you to explore the past, present and future of cities with humans at their centre. "A range of career pathways will allow you to impact sustainable cities by engaging with their economical, environmental and cultural trends."

As an urban planner, you could design new neighbourhoods or redevelop existing ones. As an architect, you could design the buildings and infrastructure needed in these new developments.

Prospects provides information about what you could do with a degree in urban planning (www.prospects.ac.uk/careers-advice/what-can-i-do-with-my-degree/urban-planning) or architecture (www.prospects.ac.uk/careers-advice/what-can-i-do-with-my-degree/ architecture).

- The International Society of City and Regional Planners works in over 90 countries to help make cities safe, resilient and sustainable: www.isocarp.org

The International Union of Architects provides information about the collaborative role that architects can play in addressing the UN Sustainable Development Goals: www.uia-architectes.org/webApi/en
JOSEPHINE AND SHILPI'S TOP TIPS

01 Work hard: dreams don't work unless we work.

02 Focus on positive inspiration, the world is full of possibilities and surprises.

03 Read widely; for instance, you can learn about urban planning by reading books on everything from classic civilisation to the urban reform movement of the 20th century.

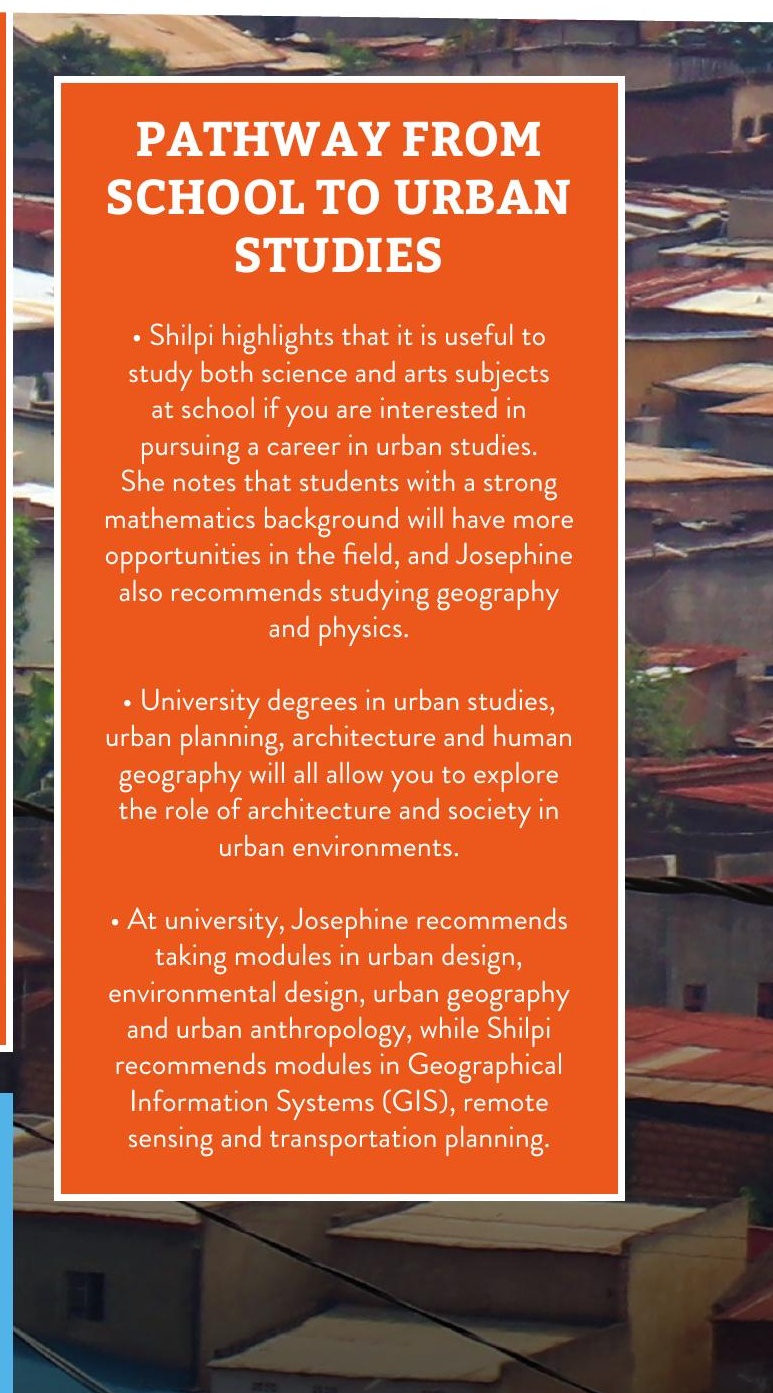


